\title{
Bifidobacteria and Escherichia coli Microbiota of Healthy Indonesian Infants in Andalas Village: Profile of Infant Diet Given Exclusive Breastfed and Formula-fed
}

\author{
Imelda Fitri ${ }^{1 *}$, Eryati Darwin ${ }^{2}$, Eva Chundrayetti ${ }^{3}$, Hotmauli Hotmauli $^{1}$, Eliya Mursyida ${ }^{4}$, Titi Lasmini $^{5}$, Nurmi Hasbi ${ }^{5}$ \\ ${ }^{1}$ Department of Midwifery, Faculty of Pharmacy and Health Science, Universitas Abdurrab, Pekanbaru, Indonesia; ${ }^{2}$ Department \\ of Histology, Faculty of Medicine, Universitas Andalas, Padang, Indonesia; ${ }^{3}$ Department of Pediatrics, Faculty of Medicine, \\ Universitas Andalas, Padang, Indonesia; ${ }^{4}$ Department of Medicine, Faculty of Medicine, Universitas Abdurrab, Pekanbaru, \\ Indonesia; ${ }^{5}$ Department of Medical Laboratory Technology, Health Academic John Paul, Pekanbaru, Indonesia
}

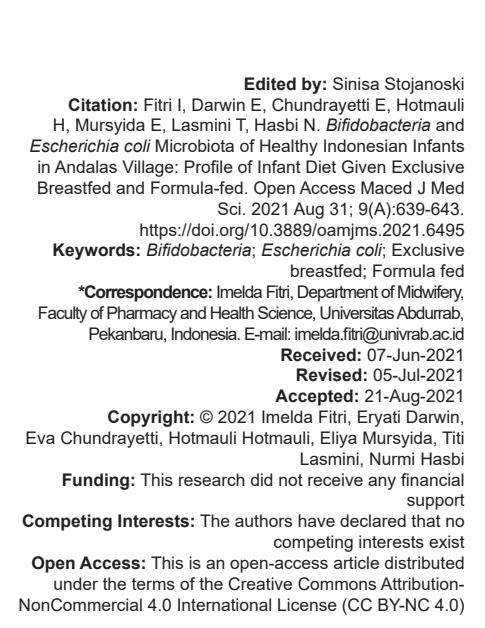

Introduction

Indonesia's neonatal mortality rate in 2017 was 15 deaths per 1000 births, while the target of sustainable development goals in 2030 for infant's mortality rate is 12 deaths per 1000 births [1].

The high infant's mortality rate in Indonesia was caused by some factors, including infection decease factor which was the highest second rate after asphyxia. Some infection decease in this present still becomes the biggest mortality of the infants, such as diarrhea [1].

Bacteria frequently cause gastrointestinal which can cause the morbidity and mortality for the infants. The pathogenesis of bacteria occurs when bacteria enters the body. Bacteria stick and attach on the host cell. After bacteria settle on the first infection, bacteria breed and spread through the lymph system to the blood flow. Infection of bacteria can stay a while, may cause complication and spread into body reaching the matched reproductive network [2].
Pathogenic bacteria are harmful bacteria which produce toxic and can cause the toxicities. Besides, pathogenic bacteria are unable to change the gastrointestinal food and liquid leftover. However, it can cause the gastrointestinal decay process [3]. In West Sumatra Province especially Padang, diarrhea is one of the ten deceases found on infants. The most frequently found diarrhea decease is gastroenteritis which is caused by bacteria [4].

Escherichia coli is one of the diarrhea bacteria. If the infant's immunity decreases, these bacteria can be pathogenic. $E$. coli produces the heat resistant enterotoxin. E. coli heats labile toxin which stimulates adenylyl cyclase enzyme to increase the permeability of epithelial cells so that the fluid in the intestines is accumulated and causes diarrhea. The E. coli heatstable toxin activates guanylate cyclase to increase intracellular cyclic guanosine monophosphate levels, inhibiting $\mathrm{NaCl}$ absorption and leading to secretory diarrhea [5]. The infants who consume bottle milk on the lower class society had higher E. coli by $26 \%$ than 
high class society of $6 \%$. Beside that the milk bottle which is prepared using unhealthy water increases the coliform colony. This often happens on the lower class society [6].

The research carried out by the World Health Organization proved that breast milk provided until 2 years old could reduce the infant's mortality rate by diarrhea. The breast milk effectiveness in controlling infection can be proved by reducing the specific decease for the infants who get breast milk than infants who get formula milk [6].

Breast milk contains each protection factor, including antibody immunoglobulin (lg)A Secretory $(\operatorname{sig} A)$. When breastfeeding, slgA will affect through the microorganism shelf on the infant's gastrointestinal and limit the entry of bacteria into blood flow through mucosa of the gastrointestinal. Immunity from the breast milk is also stimulated the formation. Pathogenic bacteria is into the maternal's alimentary canal, good lymphocyte maternal of cell $\mathrm{T}$ and cell $\mathrm{B}$ of immunoglobulin synthesis migrates to the lymphatic and at least distributed to all body including the breast. As long as breastfeeding is carried out, cells and secretion immunoglobulin component is transferred to the infant [7].

The breast milk giving also supports the beneficial bacterial growth for the newborns, thus there is a difference between microbe profile and bifidobacterial content as well as on lactobacillus between the infant's feces which is given the breast milk and formula milk. Breast milk is known to contain oligosaccharide which is able to support the Bifidobacteria and lactobacillus growth on the colony. The operated researchers showed that the bacterial colonization is very important for the infant's health [8].

Based on the health department of West Sumatra in 2017, the exclusive breastfeeding coverage in Padang city reached $67.8 \%$. This achievement is still far under national target which is $80 \%$. From 22 public health centers in Padang city, the lower exclusive breastfeeding coverage was in Andalas Village [4]. This research used conventional method and selective media to compare the infants of exclusive breastfeeding and formula fed and to compare the bacteria with delivery mode. The aim of this study was to determine Bifidobacteria and E. coli microbiota and to compare the microbiota obtained between exclusive breast fed and formula fed in Indonesian infants of Andalas Village.

\section{Material and Methods}

\section{Subjects and sampling}

Fecal samples were collected from twenty eight healthy infants aged 0-6 months old. Fourteen of them were exclusively breast fed and other 14 infants were formula fed. Fecal samples were collected from the infants. The ethical document has been reviewed by the Research Ethics Committee of the Faculty of Medicine, Universitas Andalas, Padang City Indonesia, and all of participants provided informed consent.

\section{Collection of fecal samples for microbiological analysis}

The infant's feces was taken for 1 cc reconstituted in the thioglycolate liquid $9 \mathrm{cc}$ on the sterile tube then send to Microbiology Laboratory of Dr. M. Djamil Hospital Padang Indonesia. The solution was vortexed for $5 \mathrm{~s}$ and serially diluted (to $10^{-9}$ ) in phosphate-buffered saline (PBS), $\mathrm{pH}$ 7.2. Approximately $1 \mathrm{~mL}$ of each dilution was plated onto enrichment or selective agar media.

The remaining feces were stored for 3 days at a temperature of $25^{\circ} \mathrm{C}$, which represents the average temperature during shipment. Following the incubation period, the samples were processed and the results were compared. Only samples which arrived within one or 2 days of shipment were included in the study.

\section{Identification and enumeration of} microorganisms

Viable bacterial cell counts in feces were enumerated on the following selective media: Man Rogosa Shape agar (MRSA) for Bifidobacteria and Endo agar for $E$. coli. Fecal samples were serially diluted in $1 \mathrm{~mL}$ of (PBS, $\mathrm{pH} \mathrm{7.2)} \mathrm{and} \mathrm{subsequently} \mathrm{plated} \mathrm{on}$ selective agar plates by a fully automated spiral platter capable of plating 12 agar plates simultaneously. Subsequently, the plates were incubated under either aerobic or anoxic conditions at $37^{\circ} \mathrm{C}$ for at least 2 days. Bacteria were first identified by Gram staining and colony morphologies. In addition, identifications were performed by Colony Counter. All counts were recorded as the numbers of $\log _{10}$ CFU per $\mathrm{mL}$ of sample. The following bacteria were routinely analyzed as Bifidobacteria and E. coli.

\section{Morphological characterization}

Colony characterization was performed in MRSA and Endo Agar, including the shape, size, surface, elevation, and edge formation of the colony.

\section{Cellular characterization}

This was carried out through gram staining. One loop of the single colony was taken, which further was smeared on a glass object. Crystal violet dye was dropped for $1 \mathrm{~min}$, and then washed. Mordant solution (Lugol's iodine) was dropped as the second dye for $1 \mathrm{~min}$, and then washed. Ethanol 96\% was dropped 
gently, until it was lightly crisp, and then washed. Safranin was dropped for $1 \mathrm{~min}$, and then washed. The glass object was air-dried, and then examined under the microscope. The cells of Gram-positive bacteria were purple, while the Gram-negative bacteria were red. During the motility test, an ose of the single colony was stabbed inoculated on sulfide indole motility agar medium, and then was incubated at room temperature for $2 \times 24 \mathrm{~h}$. The spread of growth was observed. A positive result was interpreted with pellicle formation on the surface of the medium.

\section{Statistical analysis}

Data are presented in Tables and Figures. Bacterial concentration was performed in the form of CFU/ml. Data analysis used SPSS version 20.0. Numerical data were analyzed using Shapiro-Wilk test first and then continued by using unpaired t-test with $p<0.05$ which was considered statistically significant.

\section{Results}

The study was conducted on breastfeeding and formula fed mothers who have infants aged 0-6 months. The total subjects were 28 subjects divided in two groups. The first group was 14 subjects obtained breast milk, while the second group containing the other 14 subjects who obtained formula fed. Bifidobacteria isolates (Figure 1).

Mean of Bifidobacteria of infants aged 0-6 months old in exclusive breastfed and formula fed (Table 1).

Mean of total E. coli colony of infants aged 0-6 months old in exclusive breast fed and formula fed (Table 2).
Table 1: Mean of total Bifidobacteria colony in infants obtaining Exclusive breast fed and formula fed

\begin{tabular}{lll}
\hline Infant diet & $\begin{array}{l}\text { Total Colony Bifidobacterium } \\
\text { Mean } \pm \text { SD }\end{array}$ & p-value \\
& $($ CFU/gram $)$ & \\
\hline Exclusive breast fed & $3.59 \times 10^{9} \pm 2.093 \times 10^{9}$ & 0.007 \\
Formula fed & $1.66 \times 10^{9} \pm 1.892 \times 10^{9}$ & \\
\hline
\end{tabular}

The morphology of colonies is similar in color, shape, surface, and elevation, but quite different on the size and edge formation. The milky white colonies have a flat edge/smooth (entire), some are uneven such as wool, round, shiny, and convex elevation with varied sizes. These isolates have morphological characters referring to Bifidobacterial genus, that is, colony with milky white color or slightly creamy, rounded form with the diameter of $0.1-0.5 \mathrm{~mm}$ as well as Gram-positive (Figure 1) [9], [10], [11], [12]

Table 2. Mean of total $E$. coli colony in infants obtaining exclusive breast fed and formula fed

\begin{tabular}{|c|c|c|}
\hline Infant diet & $\begin{array}{l}\text { Total Colony E. coli } \\
\text { Mean } \pm \text { SD } \\
(\text { CFU/g) }\end{array}$ & $p$-value \\
\hline $\begin{array}{l}\text { Exclusive breast fed } \\
\text { Formula fed }\end{array}$ & $\begin{array}{l}12.2 \times 10^{9} \pm 171.7 \times 10^{6} \\
66.8 \times 10^{9} \pm 530.2 \times 10^{6}\end{array}$ & 0.000 \\
\hline
\end{tabular}

The morphology of $E$. coli colonies of the isolated bacteria exhibited pink color, small rod shaped, and Gram-negative bacilli (Figure 2) [13].

According to Table 1, it was found that the mean Bifidobacteria of infants who exclusively breastfed was $3.59 \times 10^{9} \mathrm{CFU} / \mathrm{g}$, while the total colony of infant who obtained formula fed was $1.66 \times 10^{9} \mathrm{CFU} / \mathrm{g}$. Statistical analysis showed a significant difference of total Bifidobacteria colony between infant who obtained exclusive breast fed and formula fed $(p<0.05)$.

The mean of total $E$. coli colony of formula fed infants had increased significantly compared to the exclusive breastfed infants with $66.8 \times 10^{9} \mathrm{CFU} / \mathrm{g}$ and $12.2 \times 10^{9} \mathrm{CFU} / \mathrm{g}$, respectively. Statistical analysis showed a significant difference of total Bifidobacteria colony between infant with exclusive breast fed and formula fed $(p<0.05)$ (Table 2).
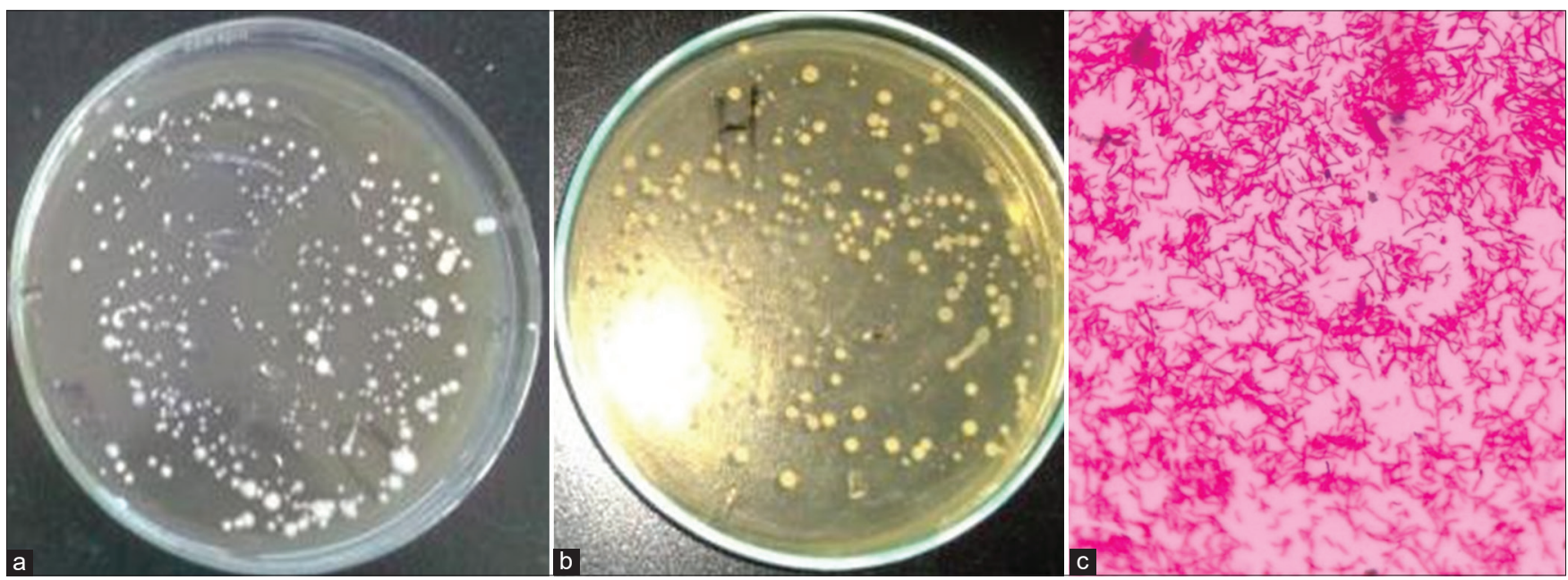

Figure 1: (a-c) Cultures of Bifidobacteria Isolates for exclusive breastfed and formula fed using Man Rogosa Shape agar and Gram staining showing Gram-negative bacteria 

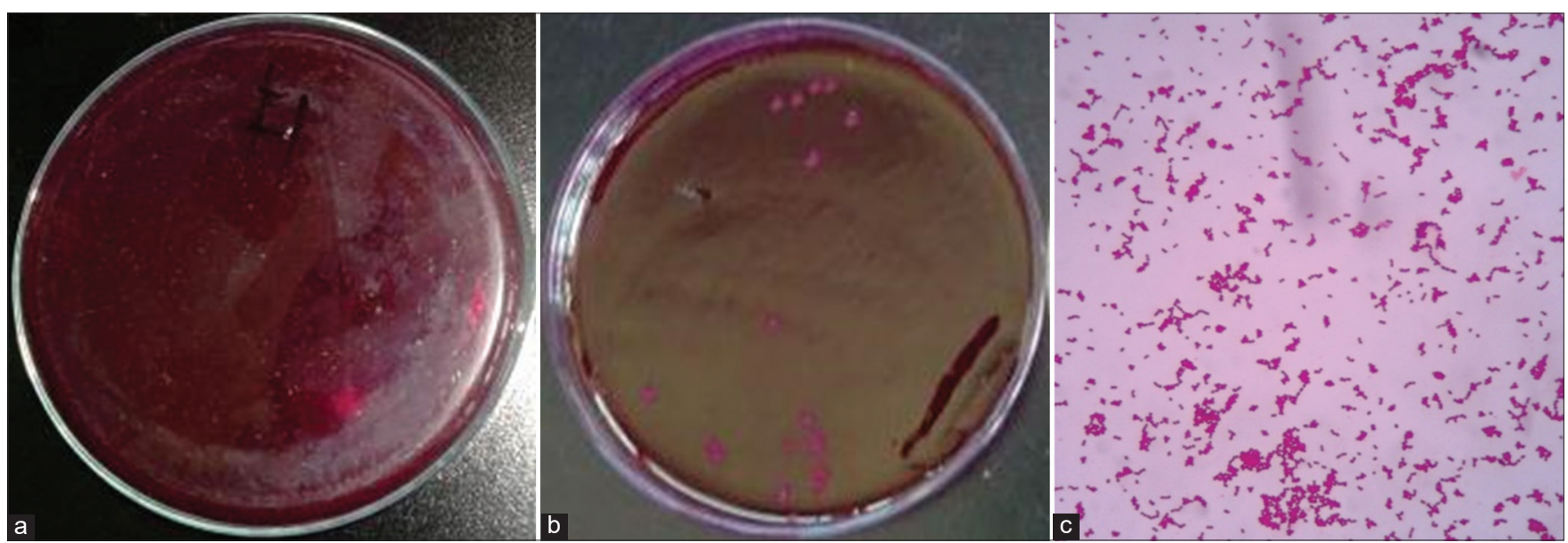

Figure 2: (a-c) Cultures of Escherichia coli isolates for exclusive breastfed and formula fed using Endo Agar and Gram staining showing Gramnegative bacteria

\section{Discussion}

The predominant intestinal microbiota in the breast fed infants was Bifidobacteria at the average of $3.59 \times 10^{9} \mathrm{CFU} / \mathrm{g}(\mathrm{p}<0.05)$. Meanwhile, the mean of total $E$. coli colony microbiota from the formula fed infants was higher which is $66.8 \times 10^{9} \mathrm{CFU} / \mathrm{g}(p<0.05)$.

The infants with exclusive breastfeeding will have more Bifidobacteria colony and lactic acid bacteria than the infants with the formula milk where Clostridium difficile colony will be higher. The domination of Bifidobacteria on the breast milk spread by the rich breast milk ingredient on the Bifidogenic such as oligosaccharides.

Oligosaccharides are carbohydrate which can promote the Bifidobacteria growth where monosaccharides are resistant through the digestive enzymes. Oligosaccharides are not produced by cow's milk, therefore in the formula milk, oligosaccharides is changed by probiotics (fructooligosaccharides, inulin, glucooligosaccharides, galacto oligosaccharides [13], [14], [15].

The current research is similar with Rinne's (2005) research, in which the research was conducted on 6 months old infants whose Bifidobacteria and lactobacillus was higher on the feces of infant's consuming breast milk than formula milk with $p<0.05$. Statistically, there was a significant difference on total colony the Bifidobacteria for the breast milk and formula milk group [16].

On this research, the high Bifidobacteria colony average for the infant which exclusive breastfeeding than non-exclusive breastfeeding is might be caused by the limited research sample on the babies with born vaginally. The factor which influences the gastrointestinal flora of the newborn baby is the childbirth method. Vaginally childbirth may allow the movement microflora from maternal to baby if it is considered by the childbirth as Caesarean section. Baby got gastrointestinal flora from the amniotic fluid which was consumed when born vaginally. Gastrointestinal flora is supposedly the same as the maternal's vagina flora. Bifidobacteria microflora activates the baby's immunity system [17].

In 1 year, microflora will be found on the newborns gastrointestinal which affects to the activation of the baby's immunity in which higher Bifidobacteria was found in infants consuming breast milk. Bifidobacteria have important role in activating the infants immunity, therefore, infants who consume formula milk have the risk for allergic and gastrointestinal infection [18].

Mammary gland is an integral part of the mucous immunity system, which fights pathogenic bacteria entering the body through the mucous way. When infant is breastfed, there is immunoglobulin from mother to baby. slgA on the breast milk especially colostrum is the early immunity bridge until the baby's gastrointestinal can produce by itself. According to some references diarrhea on the neonatal is caused by existence of the colostrum deficiency syndrome for the neonates [19].

Colostrum is produced after 2 to 4 days after the baby's birth. Colostrum is very important for the baby's immunity, growth and protection factor. Colostrum is the passive immunity type from maternal to baby. Its primary role is as antibacterial and immunity response modulation with the ability to neutralize the appeared lipopolysaccharide from the pathogenic negative gram [20].

Infants who consume formula milk have high risk for allergic because gastrointestinal mucous is still thin which leads the quickly transport the macro formula milk molecule to the blood flow, which can increase lgE and IgG, so as it can cause the histamine release, the content which appears each body allergic reaction [20].

E. coli prevalence on the infant given breast milk and formula milk was $80 \%$ compared to the infant who is given breast milk by $90 \%$, with $(p=0.004)$, indicating that there was difference in total colony between infant's given breast milk and formula milk [21], [22]. 
Bacteria are the frequently event of the gastrointestinal infection which can causes illness and mortality of the baby. E. coli is one of the diarrhea bacteria. If the infant's immunity was decreased, it could be caused by the pathogen because the bacteria produce enterotoxin which can cause the chloride and sodium absorption disorders, yet reduce the motility [5].

Infants who consume formula milk have higher risk to suffer from diarrhea and allergic. This is caused by the high breast milk nutrient value, leukocytes, enzyme, hormone, etc. which protect the baby through each infection. Besides, more uncleaned formula milk can cause the diarrhea morbidity as the unwell water manage and sterilization.

\section{Conclusion}

Exclusive breastfeeding infant's feces contain more Bifidobacteria and formula breast fed infants feces contain more $E$. coli bacteria. These findings advance our understanding of the gut microbiota in healthy infants. They also provide new evidence for infant diet as determinants of this essential microbial community in early life.

\section{References}

1. Kementrian Kesehatan Republik Indonesia. Profil Kesehatan Indonesia 2018. Jakarta: Kementerian Kesehatan Republik Indonesia; 2010. https://doi.org/10.6066/jtip.2013.24.2.121

2. Brooks Geo F, Butel JS, Morse SA. Mikrobiologi Kedokteran. Jakarta: EGC; 2010

3. Mitsuoka T. Intestinal flora and human health. Asia Pacific J Clin Nutr. 1996;5(1):2-9.

PMid:24394457

4. Dinas Kesehatan Provinsi Sumatera Barat. Laporan Kinerja Dinas Kesehatan Prov Sumbar. Padang: Dinas Kesehatan Provinsi Sumatera Barat; 2017.

5. Pawlowski SW, Warren CA, Guerrant R. Diagnosis and treatment of acute or persistent diarrhea. Gastroenterology. 2009;136(6):1874-86. gastro.2009.02.072 PMid:19457416

6. Morais TB, Morais MB, Sigulem DM. Bacterial contamination of the lacteal contents of feeding bottles in metropolitan Sao Paulo, Brazil. Bull World Health Organ. 1998;76(2):173-81.

\section{PMid:9648358}

7. Wellstart International. Lactation Management Self-study Modules Level I. Shelburne, Vermont; 2013. Available from: https://www.wellstart.org/Self-Study-Module.pdf. [Last accessed on 2021 May 24 ].

8. Azard MB, Konya T, Maughan H, Guttman DS, Field CJ, Chari RS. Gut microbiota of healthy Canadian infant : Profiles by mode of delivery and infant diet at 4 months. CMAJ. 2013;185(5):385-94. https://doi.org/10.1503/cmaj.121189 PMid:23401405

9. Wasilewska E, Bielecka M. Isolation and identification of bifidobacteria from infant gut. Pol J Food Nutr Sci 2003;12(53):90-4.

10. Lievin V, Peiffer I, Hudault S, Rochat F, Brassart D, Neeser JR, et al. Bifidobacterium strains from resident infant human gastrointestinal microflora exert antimicrobial activity. Gut. 2000;47(5):646-52. https://doi.org/10.1136/gut.47.5.646 PMid: 11034580

11. Hadadji M, Benama $R$, Saidi N, Henni DE, Kihal M. Identification of cultivable Bifidobacterium species isolated from breast-fed infants feces in West-Algeria Miloud. African J Biotechnol. 2005;4(5):422-30. https://doi. org/10.17265/2159-5828/2012.10.005

12. Hendraati PM, Kusharyati DF, Ryandini D, Oedjijono $O$ Characterization of bifidobacteria from infant feces with different mode of birth at Purwokerto, Indonesia. Biodiversitas. 2017;18(3):1265-9. https://doi.org/10.13057/biodiv/d180352

13. Zinnah MA, Bari MR, Islam MT, Hossain MT., Rahman MT, Haque $\mathrm{MH}$, et al. Characterization of Escherichia coli isolated from samples of different biological and environmental sources. Bangladesh J Vet Med. 2007;5(1-2):25-32. https://doi. org/10.3329/bjvm.v5i1.1305

14. Fujimura KE, Slusher NA, Cabana MD, Lynch SV. Role of the gut microbiota in defining human health. Expert Rev Anti Infect Ther. 2010;8(4):435-54. https://doi.org/10.1586/eri.10.14 PMid:20377338

15. Gaetano C. Immune development in late preterm neonates. Ital J Pediatr. 2014;40(2):A40. https://doi. org/10.1186/1824-7288-40-s2-a40

PMid:23734091

16. Wall R, Ross RP, Ryan CA, Hussey S, Murphy B, Fitzgerald GF et al. Role of gut microbiota in early infant development. Clin Med Pediatr. 2009;3:45-54. https://doi.org/10.4137/cmped. s2008

PMid:23818794

17. Irwanto EL; Yusrawati ; Jurnalis YD; Roslaily R; Rizanda M. Effect of Spontaneous Delivery and Elective Caesarean Section on Number of Bifidobacterium Colony in Newborns. 2011;35(2):49-52. Available from: https://garuda.ristekbrin. go.id/documents/detail/768636

18. Erick P, Zimmermann K, Rusch K, Schwiertz A, Klosterhalfen S, Frick JS. The effects of maturation on the colonic microflora in infancy and childhood. Gastroenterol Res Pract. 2009;2009:752401. https://doi.org/10.1055/s-0028-1109055 PMid: 19763278

19. Prameela KK, Mohamed AE. Breast milk Immunoprotection and the common mucosal immune system: A review. Malays $\mathrm{J}$ Nutr. 2010;16(1):1-11. PMid:22691850

20. Rawal P, Gupta V, Thapa BR. Role of colostrum in gastrointestinal infections. Indian J Pediatr. 2008;75(9):917-21.

PMid: 19011803

21. Penders J, Thijs C, Vink C, Stelma FF, Snijders B, Kummeling I, et al. Factors influencing the composition of the intestinal microbiota in early infancy. Pediatrics. 2006;118(2):511-21. https://doi.org/10.1542/peds.2005-2824

PMid:16882802

22. Barcella L, Barbaro AP, Rogolino SB. Colonial morphology of Escherichia coli: Impact of detection in clinical specimens. Microbiol Med. 2016;31(2):51-5. https://doi.org/10.4081/mm.2016.5636 